\title{
Hydrocarbon molar water solubility predicts NMDA vs. GABA A receptor modulation
}

\author{
Robert J Brosnan* and Trung L Pham
}

\begin{abstract}
Background: Many anesthetics modulate 3-transmembrane (such as NMDA) and 4-transmembrane (such as $G A B A_{A}$ ) receptors. Clinical and experimental anesthetics exhibiting receptor family specificity often have low water solubility. We hypothesized that the molar water solubility of a hydrocarbon could be used to predict receptor modulation in vitro.
\end{abstract}

Methods: $G_{A B A}\left(a_{1} \beta_{2} \gamma_{2 s}\right)$ or NMDA (NR1/NR2A) receptors were expressed in oocytes and studied using standard two-electrode voltage clamp techniques. Hydrocarbons from 14 different organic functional groups were studied at saturated concentrations, and compounds within each group differed only by the carbon number at the w-position or within a saturated ring. An effect on $\mathrm{GABA}_{\mathrm{A}}$ or NMDA receptors was defined as a $10 \%$ or greater reversible current change from baseline that was statistically different from zero.

Results: Hydrocarbon moieties potentiated $\mathrm{GABA}_{A}$ and inhibited NMDA receptor currents with at least some members from each functional group modulating both receptor types. A water solubility cut-off for NMDA receptors occurred at $1.1 \mathrm{mM}$ with a $95 \% \mathrm{Cl}=0.45$ to $2.8 \mathrm{mM}$. NMDA receptor cut-off effects were not well correlated with hydrocarbon chain length or molecular volume. No cut-off was observed for GABA receptors within the solubility range of hydrocarbons studied.

Conclusions: Hydrocarbon modulation of NMDA receptor function exhibits a molar water solubility cut-off. Differences between unrelated receptor cut-off values suggest that the number, affinity, or efficacy of proteinhydrocarbon interactions at these sites likely differ.

\section{Background}

Inhaled anesthetics interact with putative cell receptor targets in a manner uncharacteristic of most other pharmacologic agents. They exhibit immobilization efficacy in all animals, both vertebrates and invertebrates, and even in protozoa and plants. The inhaled agents range in diversity from single elements to diatomic molecules to complex hydrocarbons and share no conserved size, shape, or functional groups. Most agents also modulate multiple phylogenetically unrelated cell targets and generally inhibit excitatory channels or receptors and potentiate inhibitory ones, complicating the identification of a drug-receptor structural motif predictive of anesthetic molecular action [1].

Attempts to determine how disparate drugs act on so many unrelated receptors-and to define those targets

\footnotetext{
* Correspondence: rjbrosnan@ucdavis.edu

Department of Surgical and Radiological Sciences, School of Veterinary Medicine, University of California, Davis, CA 95616, USA
}

essential to inhaled anesthetic actions-have thus far proved illusory. Consequently, in the present study, we posed the opposite question: Why are some anesthetics unable to modulate certain anesthetic-sensitive ion channels or receptors, even at supra-pharmacologic concentrations? To answer this question, we restricted consideration to two unrelated ion channels in particular: the $\mathrm{N}$-methyl-d-aspartate (NMDA) receptor, a member of the 3-transmembrane (TM3) ion channel family, and the $\gamma$-aminobutyric acid type $\mathrm{A}\left(\mathrm{GABA}_{\mathrm{A}}\right)$ receptor, a member of the 4-transmembrane (TM4) ion channel family. Strong evidence supports the role of both receptors in mediating various endpoints of general anesthesia, including immobility and amnesia [2-6]. Within the NMDA and $\mathrm{GABA}_{\mathrm{A}}$ channel proteins, hydrophilic or amphipathic cavities or pockets have been postulated near the solvent interface and within transmembrane segments of several subunits $[7,8]$. Presumably, such cavities might conceivably contain solvent molecules or nothing at all, though it should be 
thermodynamically less favorable to maintain a vacuum within a pocket that is sufficiently large and polar enough to accommodate water.

The binding affinity of water within each pocket on an ion channel can be expressed as a standard dissociation constant, and the ability of a drug to displace water and either completely or partially fill the pocket can be expressed as a standard equilibrium constant. Since structures of phylogenetically unrelated channels are different, the hydrophilicity of their respective pockets should not be conserved. Therefore, dissociation constants are expected to be different for water bound within pockets of different channels. Consequently, the minimum concentration of drug necessary to displace water within a pocket capable of inducing a functional conformational change should be different between unrelated channels. If the drug cannot reach a concentration within the aqueous phase sufficient to displace water within the protein modulatory pocket, then that drug should exert no pharmacologic effect on the channel, even when delivered at a saturated aqueous phase concentration. The physical property that defines this maximum (saturated) concentration of a drug in the aqueous phase is the molar water solubility.

The effects of a number of conventional (modern and historic) and experimental anesthetics on NMDA and $\mathrm{GABA}_{\mathrm{A}}$ receptors have been studied previously. When plotted in order of their calculated molar water solubilities (Figure 1), there is an abrupt change in the ability of compounds to modulate NMDA receptors. Drugs with water solubility greater than about $1 \mathrm{mM}$ all modulate NMDA and $\mathrm{GABA}_{\mathrm{A}}$ currents when administered in sufficiently large concentrations. However, drugs with lower molar water solubility modulate only $\mathrm{GABA}_{\mathrm{A}}$ or neither receptor type. These data suggest that molar water solubility may predict an NMDA receptor cut-off effect at values less than $1 \mathrm{mM}$ and are consistent with nonspecific interactions in which water displaced from modulatory pockets on the NMDA receptor contribute, at least in part, to molecular mechanisms of action. Compounds unable to reach approximately $1 \mathrm{mM}$ aqueous concentration may thus be unable to competitively displace water within any of the NMDA critical modulatory sites.

We hypothesized that hydrocarbon molar water solubility below this critical cut-off value is associated with loss of NMDA receptor modulation, but not $\mathrm{GABA}_{\mathrm{A}}$ receptor modulation. As tests agents, we considered 14 different series of normal hydrocarbon chains or rings, where molecules within each series differed only by the length of the $\Omega$ chain or substitutent alkyl groups (Table 1). Because different functional groups differ in hydrophilicity, the length and volume of the hydrocarbon chain needed to achieve a given molar water solubility will likewise differ. Thus, if the hypothesis is correct, then observed cut-off responses should correlate with hydrocarbon molar water solubility rather than hydrocarbon size.

Although generally advocated to study anesthetic effects at clinically-relevant concentrations, we proposed to test this hypothesis at saturated aqueous drug concentrations for 3 reasons. First, because an aqueous binding site is postulated, it is important to study drug effects at an interfacial concentration that can be directly related to a bulk aqueous concentration. However, anesthetics do not distribute equally through the lipid bilayer. Halothane shows a preference for the phospholipid headgroup interface [27]. Xenon atoms prefer regions at the lipid-water interface and the central region of the bilayer [28]. The anesthetics cyclopropane, nitrous oxide, desflurane, isoflurane, and 1,1,2-trifluoroethane all preferentially

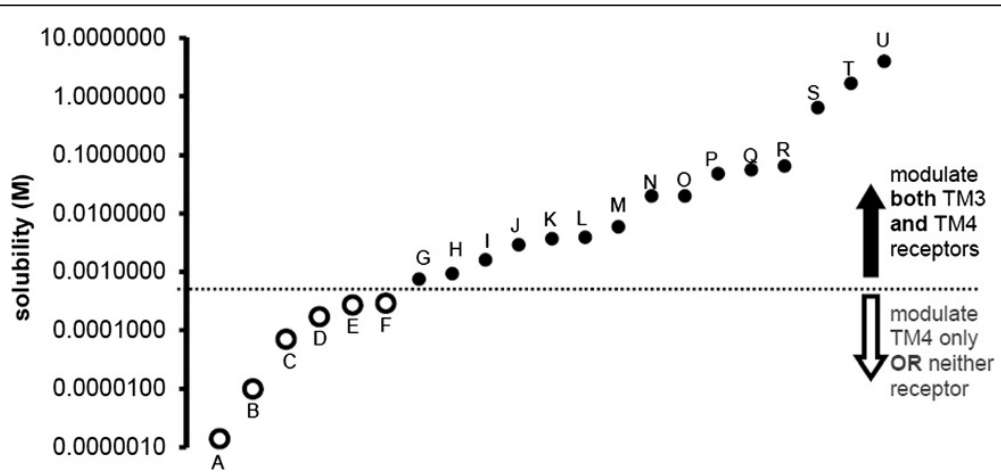

Figure 1 Summary of ion channel modulation as a function of calculated anesthetic molar solubility in unbuffered water at $25^{\circ} \mathrm{C}$ (values from SciFinder Scholar). Drugs that modulate 4-transmembrane receptors (TM4) or neither receptor type are shown as open circles $(\mathrm{O}, \mathrm{A}-\mathrm{F})$ below the dotted horizontal solubility line. Drugs that modulate both 3-transmembrane (TM3) and TM4 receptors are shown as small black circles $(\bullet, G-U)$ above the dotted horizontal solubility line. A = nonane (unpublished data), B= midazolam [9], $C=$ diazepam [10], D= undecanol [11], $\mathrm{E}=$ etomidate [12], $\mathrm{F}=1,2$-dichlorohexafluorocyclobutane [13], $\mathrm{G}=$ sevoflurane [14-17], $\mathrm{H}=$ propofol [18,19], I = ketamine [12,16,20], J = isoflurane $[14-16,21,22], K=$ enflurane $[15,23], L=$ dizocilpine $[20,24], M=$ desflurane $[16,17], N=$ halothane $[14,22,23], O=$ cyclopropane $[22,25], P=$ chloroform [22], Q = 2,6-dimethylphenol [26], $\mathrm{R}=$ methoxyflurane [14,15,23], $\mathrm{S}=$ diethyl ether [15,23], $\mathrm{T}=$ nitrous oxide [21,22], $\mathrm{U}=$ ethanol [21]. 
Table 1 Source, purity and physical properties of study compounds

\begin{tabular}{|c|c|c|c|c|c|c|c|c|}
\hline Compound & CAS\# & MW (amu) & $P_{\text {vap }}(\mathrm{mmHg})$ & Solubility (M) & Carbon (\#) & Volume $\left(\AA^{3}\right)$ & Source & Purity (\%) \\
\hline \multicolumn{9}{|l|}{ Alcohols } \\
\hline 1-decanol & $112-30-1$ & 158.28 & $1.48 \times 10^{-2}$ & $6.5 \times 10^{-4}$ & 10 & 317 & Aldrich & $>99$ \\
\hline 1-undecanol & $112-42-5$ & & $5.10 \times 10^{-3}$ & $1.7 \times 10^{-4}$ & 11 & 344 & Acros & 98 \\
\hline 1-dodecanol & $112-53-8$ & 172.31186 .33 & $2.09 \times 10^{-3}$ & $4.1 \times 10^{-5}$ & 12 & 372 & $\mathrm{TCl}$ & 99 \\
\hline \multicolumn{9}{|l|}{ Alkanes } \\
\hline butane & $106-97-8$ & 58.12 & $1.92 \times 10^{3}$ & $1.4 \times 10^{-3}$ & 4 & 156 & Matheson & 99.99 \\
\hline pentane & $109-66-0$ & 72.15 & $5.27 \times 10^{2}$ & $4.3 \times 10^{-4}$ & 5 & 184 & & $>99$ \\
\hline hexane & $110-54-3$ & 86.18 & $1.51 \times 10^{2}$ & $1.2 \times 10^{-4}$ & 6 & 211 & Aldrich Acros & $>99$ \\
\hline \multicolumn{9}{|l|}{ Aldehydes } \\
\hline octanal & $124-13-0$ & 128.21 & $2.07 \times 10^{0}$ & $5.4 \times 10^{-3}$ & 8 & 262 & Aldrich & 99 \\
\hline nonanal & $124-19-6$ & 142.24 & $5.32 \times 10^{-}$ & $2.3 \times 10^{-3}$ & 9 & 289 & Aldrich & 95 \\
\hline decanal & $112-31-2$ & 156.27 & 1 & $9.8 \times 10^{-4}$ & 10 & 316 & Aldrich & 98 \\
\hline undecanal & $112-44-7$ & 170.29 & $2.07 \times 10^{-1} 8.32 \times 10^{-2}$ & $4.2 \times 10^{-4}$ & 11 & 344 & Aldrich & 97 \\
\hline \multicolumn{9}{|l|}{ Alkenes } \\
\hline 1-pentene & $109-67-1$ & 70.13 & $6.37 \times 10^{2}$ & $1.4 \times 10^{-3}$ & 5 & 176 & Aldrich & 99 \\
\hline 1-hexene & $592-41-6$ & 84.16 & $1.88 \times 10^{2}$ & $4.2 \times 10^{-4}$ & 6 & 203 & Aldrich & $>99$ \\
\hline \multicolumn{9}{|l|}{ Alkynes } \\
\hline 1-hexyne & $693-02-7$ & 82.14 & $1.35 \times 10^{2}$ & $2.9 \times 10^{-3}$ & 6 & 184 & Aldrich & 97 \\
\hline 1-heptyne & $628-71-7$ & 96.17 & $4.35 \times 10^{1}$ & $6.6 \times 10^{-4}$ & 7 & 212 & Acros & 99 \\
\hline 1-octyne & $629-05-0$ & 110.2 & $1.44 \times 10^{1}$ & $1.9 \times 10^{-4}$ & 8 & 239 & Acros & 99 \\
\hline \multicolumn{9}{|l|}{ Amines } \\
\hline 1-octadecanamine & $124-30-1$ & 269.51 & $4.88 \times 10^{-5}$ & $1.3 \times 10^{-3}$ & 18 & 546 & $\mathrm{TCl}$ & 97 \\
\hline 1-eicosanamine & $10525-37-8$ & 297.56 & $8.96 \times 10^{-6}$ & $2.7 \times 10^{-4}$ & 20 & 601 & Rambus & 95 \\
\hline \multicolumn{9}{|l|}{ Benzenes } \\
\hline 1,3-dimethylbenzene & $108-38-3$ & 106.17 & $7.61 \times 10^{0}$ & $1.2 \times 10^{-3}$ & 8 & 202 & Aldrich & $>99$ \\
\hline 1,3-diethylbenzene & $141-93-5$ & 134.22 & $1.15 \times 10^{0}$ & $6.6 \times 10^{-5}$ & 10 & 257 & Fluka & $>99$ \\
\hline \multicolumn{9}{|l|}{ Cycloalkanes } \\
\hline cyclopentane & $287-92-3$ & 70.13 & $3.14 \times 10^{2}$ & $3.3 \times 10^{-3}$ & 5 & 147 & Aldrich & $>99$ \\
\hline cyclohexane & $110-82-7$ & 84.16 & $9.37 \times 10^{1}$ & $1.0 \times 10^{-3}$ & 6 & 176 & Aldrich & $>99.7$ \\
\hline \multicolumn{9}{|l|}{ Ethers } \\
\hline dibutylether & $142-96-1$ & 130.23 & $7.10 \times 10^{0}$ & $1.6 \times 10^{-2}$ & 8 & 277 & Aldrich & 99.3 \\
\hline dipentylether & $693-65-2$ & & $1.00 \times 10^{0}$ & $3.0 \times 10^{-3}$ & 10 & 331 & Fluka & $>98.5$ \\
\hline dihexylether & $112-58-3$ & 158.28186 .33 & $1.48 \times 10^{-1}$ & $5.8 \times 10^{-4}$ & 12 & 386 & Aldrich & 97 \\
\hline \multicolumn{9}{|l|}{ Esters } \\
\hline ethyl heptanoate & $106-30-9$ & 158.24 & $6.02 \times 10^{-1}$ & $5.4 \times 10^{-3}$ & 9 & 299 & MP Bio & 99 \\
\hline ethyl octanoate & $106-32-1$ & & $2.24 \times 10^{-1}$ & $2.1 \times 10^{-3}$ & 10 & 327 & Aldrich & $>99$ \\
\hline ethyl decanoate & $110-38-3$ & 172.26200 .32 & $3.39 \times 10^{-2}$ & $4.4 \times 10^{-4}$ & 12 & 381 & $\mathrm{TCl}$ & 98 \\
\hline \multicolumn{9}{|l|}{ Haloalkanes } \\
\hline 1-fluoropentane & $592-50-7$ & 90.14 & $1.84 \times 10^{2}$ & $3.9 \times 10^{-3}$ & 5 & 193 & Aldrich & 98 \\
\hline 1-fluorohexane & $373-14-8$ & 104.17 & $6.06 \times 10^{1}$ & $1.2 \times 10^{-3}$ & 6 & 220 & Acros & $>99$ \\
\hline 1-fluoroctane & $463-11-6$ & 132.22 & $7.09 \times 10^{0}$ & $1.3 \times 10^{-4}$ & 8 & 275 & Aldrich & 98 \\
\hline
\end{tabular}


Table 1 Source, purity and physical properties of study compounds (Continued)

\begin{tabular}{|c|c|c|c|c|c|c|c|c|}
\hline \multicolumn{9}{|l|}{ Ketones } \\
\hline 2-decanone & $693-54-9$ & 156.27 & $2.48 \times 10^{-1}$ & $3.2 \times 10^{-3}$ & 10 & 316 & $\mathrm{TCl}$ & $>99$ \\
\hline 2-undecanone & $112-12-9$ & & $9.78 \times 10^{-2}$ & $1.4 \times 10^{-3}$ & 11 & 343 & Acros & 98 \\
\hline 2-dodecanone & 6175-49-1 & 170.29184 .32 & $3.96 \times 10^{-2}$ & $5.8 \times 10^{-4}$ & 12 & 371 & $\mathrm{TCl}$ & 95 \\
\hline \multicolumn{9}{|l|}{ Sulfides } \\
\hline 1-(ethylthio)-hexane & $7309-44-6$ & 146.29 & $8.16 \times 10^{-1}$ & $2.8 \times 10^{-3}$ & 8 & 289 & Pfaltz & 97 \\
\hline 1-(ethylthio)-octane & $3698-94-0$ & 174.35 & $1.08 \times 10^{-1}$ & $5.0 \times 10^{-4}$ & 10 & 344 & Pfaltz & 97 \\
\hline \multicolumn{9}{|l|}{ Thiols } \\
\hline 1-pentanethiol & $110-66-7$ & 104.21 & $1.42 \times 10^{1}$ & $1.5 \times 10^{-3}$ & 5 & 207 & Aldrich & 98 \\
\hline 1-hexanethiol & $111-31-9$ & 118.24 & $4.50 \times 10^{0}$ & $5.1 \times 10^{-4}$ & 6 & 235 & $\mathrm{TCl}$ & 96 \\
\hline
\end{tabular}

are calculated estimates (rather than measured values) refight (MW), vapor pressure at 25

concentrate at the interface between water and hexane, [29] but the nonimmobilizer perfluoroethane does not exhibit a hydrophilic-hydrophobic interfacial maxima [29]. Nonetheless, even without knowing the membrane distribution profile of an anesthetic, the interfacial concentration can be assumed maximal at a saturating aqueous phase concentration at equilibrium; thus drug responses are compared at their respective relative maximum interfacial concentrations.

Second, different anesthetic endpoints are achieved at different drug concentrations. Thus, a drug could exhibit relative receptor specificity; that is to say, a drug may act preferentially at one receptor to achieve one endpointsuch as amnesia-but act on additional receptors when administered at higher concentrations to achieve other endpoints-such as immobility. Failure to modulate a receptor when a drug is delivered at a saturated concentration implies a null receptor response at lower drug concentrations and for any therapeutic endpoint.

Third, the drug concentrations that produce different anesthetic endpoints-amnesia, unconsciousness and immobility-are unknown for many experimental compounds. Some anesthetic endpoints may not even be achievable with some compounds, such as the nonimmobilizers. Absolute receptor specificity means that there is also relative specificity for any drug effect produced. Accordingly, comparisons of receptor effects using saturated concentrations in vitro are not prepositioned upon knowledge of in vivo drug anesthetic effects.

Hence, this study aimed to test whether NMDA versus $\mathrm{GABA}_{\mathrm{A}}$ receptor modulation was correlated with calculated molar water solubility "cut-off" values for diverse series of hydrocarbon functional groups.

\section{Methods}

\section{Oocyte collection and receptor expression}

An ovary from tricaine-anesthetized Xenopus laevis frogs was surgically removed using a protocol approved by the
Institutional Animal Care and Use Committee at the University of California, Davis (Protocol \#12030). Following manual disruption of the ovarian lobule septae, the ovary was incubated in $0.2 \%$ Type I collagenase (Worthington Biochemical, Lakewood, NJ) to defolliculate oocytes which were washed and stored in fresh and filtered modified Barth's solution composed of $88 \mathrm{mM}$ $\mathrm{NaCl}, 1 \mathrm{mM} \mathrm{KCl}, 2.4 \mathrm{mM} \mathrm{NaHCO}, 20 \mathrm{mM}$ HEPES, $0.82 \mathrm{mM} \mathrm{MgSO}_{4}, 0.33 \mathrm{mM} \mathrm{Ca}\left(\mathrm{NO}_{3}\right)_{2}, 0.41 \mathrm{mM} \mathrm{CaCl}_{2}$, $5 \mathrm{mM}$ sodium pyruvate, gentamycin, penicillin, streptomycin, and corrected to $\mathrm{pH}=7.4$. All salts and antibiotics were A.C.S. grade (Fisher Scientific, Pittsburgh, PA).

Clones used were provided as a gift from Dr. R.A. Harris (University of Texas, Austin) and were sequenced and compared to references in the National Center for Biotechnology Information database to confirm the identity of each gene. $\mathrm{GABA}_{\mathrm{A}}$ receptors were expressed using clones for the human $\mathrm{GABA}_{\mathrm{A}} \alpha 1$ and the rat $\mathrm{GABA}_{\mathrm{A}} \beta 2$ and $\gamma 2 \mathrm{~s}$ subunits in pCIS-II vectors. Approximately 0.25-1 ng total plasmid mixture containing either $\alpha_{1}, \beta_{2}$, or $\gamma_{2}$ genes in a respective ratio of 1:1:10 was injected intranuclearly through the oocyte animal pole and studied 2-4 days later. These plasmid ratios ensured incorporation of the $\gamma$ subunit into expressed receptors, as confirmed via receptor potentiation to $10 \mu \mathrm{M}$ chlordiazepoxide or insensitivity to $10 \mu \mathrm{M}$ zinc chloride during co-application with GABA. In separate oocytes, glutamate receptors were expressed using rat NMDA NR1 clones in a pCDNA3 vector and rat NMDA NR2A clones in a Bluescript vector. RNA encoding each subunit, prepared using a commercial transcription kit (T7 mMessage mMachine, Ambion, Austin, TX), was mixed in a 1:1 ratio, and 1-10 ng of total RNA was injected into oocytes and studied 1-2 days later. Oocytes injected with similar volumes of water served as controls.

\section{$\mathrm{GABA}_{\mathrm{A}}$ receptor electrophysiology studies}

Oocytes were studied in a $250 \mu \mathrm{L}$ linear-flow perfusion chamber with solutions administered by syringe pump at 
$1.5 \mathrm{ml} / \mathrm{min}$ with gastight glass syringes and Teflon tubing. Oocyte $\mathrm{GABA}_{\mathrm{A}}$ currents were studied using standard two-electrode voltage clamping techniques at a holding potential of $-80 \mathrm{mV}$ using a $250 \mu \mathrm{L}$ channel linear-flow perfusion chamber with solutions administered by syringe pump at $1.5 \mathrm{~mL} / \mathrm{min}$.

Frog Ringer's (FR) solution composed of $115 \mathrm{mM}$ $\mathrm{NaCl}, 2.5 \mathrm{mM} \mathrm{KCl}, 1.8 \mathrm{mM} \mathrm{CaCl}_{2}$, and $10 \mathrm{mM}$ HEPES prepared in 18.2 $\mathrm{M} \Omega \mathrm{H}_{2} \mathrm{O}$ and filtered and adjusted to $\mathrm{pH}=7.4$ was used to perfuse oocytes. Agonist solutions also contained 20-to-40 $\mu \mathrm{M}$, equal to an $\mathrm{EC}_{10-20}$, of 4aminobutanoic acid (FR-GABA) [30-32]. After FR perfusion for $5 \mathrm{~min}$, oocytes were exposed to $30 \mathrm{sec}$ FR-GABA followed by another 5 min FR washout; this was repeated until stable $\mathrm{GABA}_{\mathrm{A}}$-elicited peaks were obtained. Next, FR containing a saturated solution of the study drug (Table 1) - or for gaseous study compounds a vapor pressure equal to $90 \%$ of barometric pressure with balance oxygen-was used to perfuse the oocyte chamber for 2 min followed by perfusion with a FR-GABA solution containing the identical drug concentration for $30 \mathrm{sec}$. FR was next perfused for $5 \mathrm{~min}$ to allow drug washout, and oocytes were finally perfused with FR-GABA for $30 \mathrm{sec}$ to confirm return of currents to within $10 \%$ of the initial baseline response.

\section{NMDA receptor electrophysiology studies}

Methods for measurement of whole-cell NMDA receptor currents have been described [33,34]. Briefly, baseline perfusion solutions were the same as for $\mathrm{GABA}_{\mathrm{A}}$ with the substitution of equimolar $\mathrm{BaCl}_{2}$ for calcium salts and the addition of $0.1 \mathrm{mM}$ EGTA; this constituted barium frog Ringer's solution (BaFR). Agonist solutions for NMDA studies also contained $0.1 \mathrm{mM}$ glutamate (E) and $0.01 \mathrm{mM}$ glycine $(\mathrm{G})$ to constitute a BaFREG solution that produced a NMDA receptor current $\geq \mathrm{EC}_{99}$.

The syringe pump and perfusion chamber apparatus as well as the clamp holding potential and baseline-agonist exposure protocols were identical to that described for the $\mathrm{GABA}_{\mathrm{A}}$ studies. The same test compounds, concentrations, and preparative methods were used in NMDA voltage clamp studies as in the $\mathrm{GABA}_{\mathrm{A}}$ voltage clamp studies (Table 1).

\section{Response calculations and data analysis}

Modulating drug responses were calculated as the percent of the control (baseline) peak as follows: $100 \cdot \frac{I_{D}}{I_{B}}$, where $I_{D}$ and $I_{B}$ were the peak currents measured during agonist + drug and agonist baseline perfusions, respectively. When present, direct receptor activation by a drug was similarly calculated as a percent of the agonist response. Average current responses for each drug and channel were described by mean \pm SD. A lack of receptor response (cut-off) was defined as a $<10 \%$ change from baseline current that was statistically indistinguishable from zero using a two-tailed Student t-test. Hence, drug responses $\geq 110 \%$ of the baseline peak showed potentiation of receptor function, and drug responses $\leq 90 \%$ of the baseline peak showed inhibition of receptor function.

The $\log _{10}$ of the calculated solubility $\left(\log _{10} S\right)$ for compounds immediately below and above the cut-off for each hydrocarbon functional group were used to determine the receptor cut-off. For each hydrocarbon, there was a "grey area" of indeterminate solubility effect (Figure 2) between sequentially increasing hydrocarbon chain lengths. Mean solubility cut-offs were calculated as the average $\log _{10} \mathrm{~S}$ for the least soluble compound that modulated receptor function and the most soluble neighboring compound for which no effect was observed. From this result, a 95\% confidence interval for $\log _{10} \mathrm{~S}$ was calculated for receptor solubility cut-offs.

\section{Results}

Hydrocarbon effects on NMDA and $\mathrm{GABA}_{\mathrm{A}}$ receptors are summarized in Table 2, and sample recordings are presented in Figure 2. All of the compounds tested positively modulated $\mathrm{GABA}_{\mathrm{A}}$ receptor function, and a few of the 5-to-6 carbon compounds caused mild direct $\mathrm{GABA}_{\mathrm{A}}$ receptor activation, particularly the 1 -fluoroalkanes and thiols. Mild direct receptor activation also occurred with dibutylether. With the exception of the aldehydes, alkynes, and cycloalkanes, $\mathrm{GABA}_{\mathrm{A}}$ receptor inhibition tended to decrease with increasing hydrocarbon chain length. No water solubility cut-off effect was observed for $\mathrm{GABA}_{\mathrm{A}}$ receptors for the compounds tested.

In contrast, NMDA receptors currents were decreased by the shorter hydrocarbons within each functional group (Table 1), but lengthening the hydrocarbon chain eventually produced a null response-a cut-off effect. No direct hydrocarbon effects on NMDA receptor function were detected in the absence of glutamate and glycine agonist.

The cut-off effect for NMDA receptor current modulation was associated with a hydrocarbon water solubility of $1.1 \mathrm{mM}$ with a 95\% confidence interval between $0.45 \mathrm{mM}$ and $2.8 \mathrm{mM}$ (Figure 3). More soluble hydrocarbons consistently inhibited NMDA receptor currents when applied at saturated aqueous concentrations, and hydrocarbons below this range had no appreciable effect on NMDA receptor function. Moveover, during the course of the study, water solubility was sufficiently predictive of an NMDA receptor cut-off so as to require identify and testing of only single pair of compounds bracketing this critical solubility value, as occurred with the alkenes, amines, cyclic hydrocarbons, and sulfurcontaining compounds.

Increasing hydrocarbon chain length decreases water solubility, but also increases molecular size. However, 


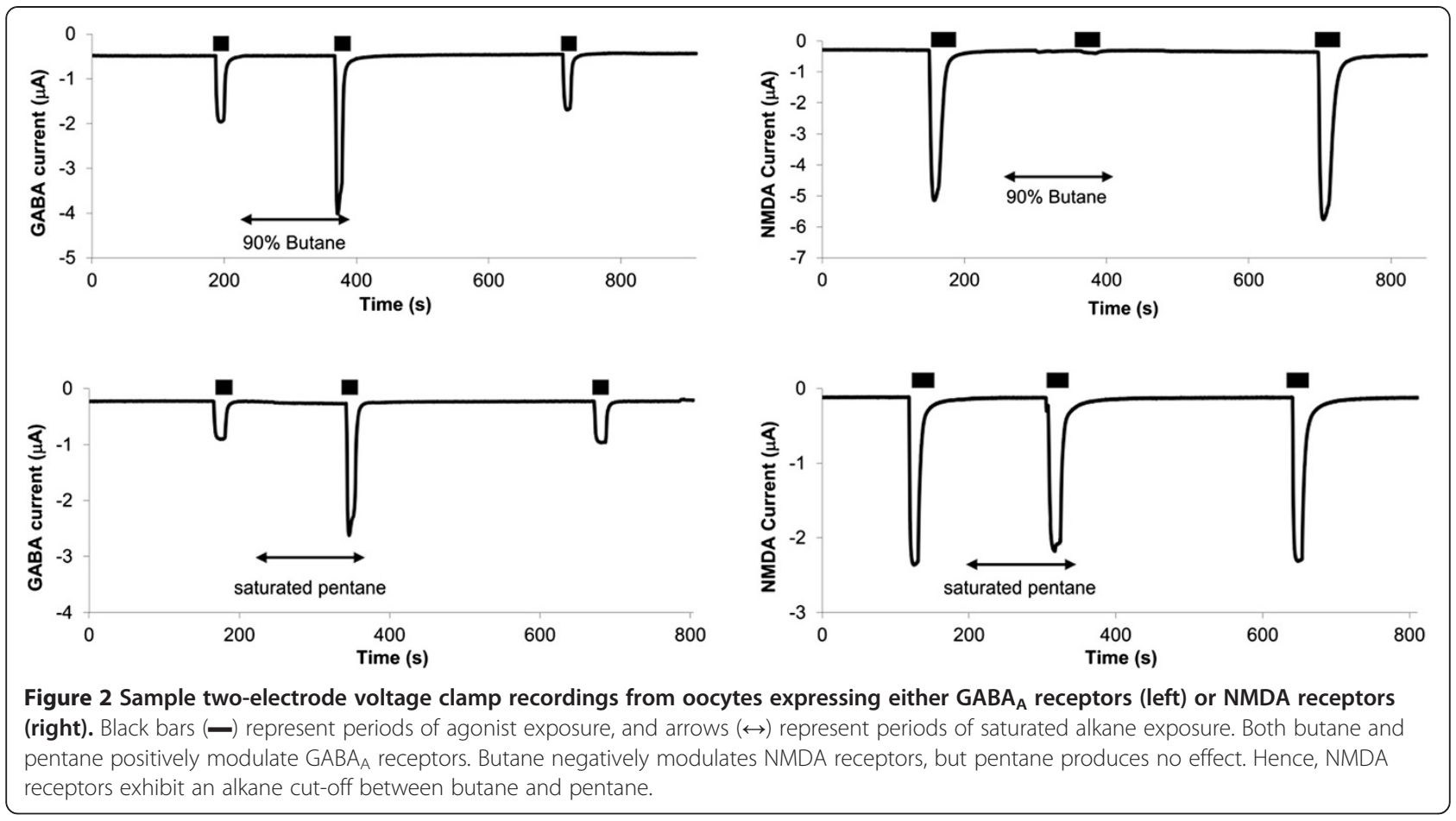

when graphed as a function of either carbon number (Figure 4) or molecular volume (Figure 5), the observed NMDA receptor cut-off effects show no consistent pattern. For example, the n-alkanes, 1-alkenes, and 1-alkynes show progressive lengthening of the hydrocarbon chain cut-off, presumably as a result of the increasing aqueous solubility conferred by the double and triple carbon bonds, respectively. There was also tremendous variation in molecular size of compounds exhibiting NMDA receptor cut-off. Alkanes exhibited NMDA receptor cut-off between butane and pentane, respectively 4 and 5 carbons in length, whereas the primary amines exhibited cut-off between 1-octadecanamine and 1-eicosanamine, respectively 18 and 20 carbons in length. As expected, the molecular volume of these compounds associated with NMDA receptor cut-off is also quite different, with the primary amine being over 3 times larger than the alkane.

\section{Discussion}

NMDA receptor modulation is associated with an approximate $1.1 \mathrm{mM}$ water solubility cut-off (Figure 3). In contrast, $\mathrm{GABA}_{\mathrm{A}}$ receptors potentiated all study compounds; this may be because a $\mathrm{GABA}_{\mathrm{A}}$ cut-off occurs at a lower water solubility value. Sequentially increasing hydrocarbon length to find a receptor cut-off effect potentially introduces confounding factors of carbon number and molecular volume that could in turn be responsible for the cut-off effect [35-38]. However, an aggregate comparison of cut-off values for all hydrocarbon groups as a function of carbon number (Figure 4) or molecular volume (Figure 5) shows no discernible pattern, suggesting that these physical properties are unlikely the primary limiting factors for drug-receptor modulation.

The correlation between molar water solubility and the NMDA receptor cut-off suggests hydrocarbons compete with water for amphipathic binding pockets within anesthetic-sensitive ion channels. Most inhaled anesthetics exhibit low-affinity binding on receptors as evidenced by generally large median effective concentrations for anesthesia-in the 230-290 $\mu \mathrm{M}$ range for isoflurane and halothane [39] - as compared to agents that exert narcotic effects via a singular or primary molecular targets. These specific interactions-exemplified by ketamine antagonism of NMDA receptors [12], etomidate agonism of $\mathrm{GABA}_{\mathrm{A}}$ receptors [40], dexmedetomidine agonism of $\alpha_{2}-$ adrenoreceptors [41], and morphine agonism of $\mu$-opioid receptors [42] -typically require only a few $\mu \mathrm{M}$ or less of drug and are consistent with high affinity interactions to resulting in induced fit binding. Instead, volatile anesthetics likely bind to pre-existing pockets and surfaces on or within the protein [43]. Amphipathic pockets likely contain water molecules; when these are displaced by amphipathic drugs, fewer strong hydrophilic interactions and more hydrophobic interactions are possible with amino acid side chains in the cavity. We propose such nonspecific binding causes a change in pocket shape and, in consequence, the larger three-dimensional protein structure that affects channel gating or conductance.

Hydrocarbons act as hydrogen bond donors-or in the case of electrophiles, as hydrogen bond acceptors-with 


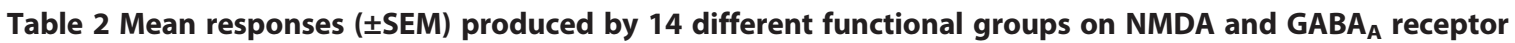
modulation, expressed as a percent of the control agonist peak, using standard two-electrode voltage clamp techniques with 5-6 oocytes each

\begin{tabular}{|c|c|c|c|c|c|c|}
\hline \multirow[t]{2}{*}{ Compound } & \multicolumn{3}{|c|}{ NMDA } & \multicolumn{3}{|c|}{$\mathrm{GABA}_{\mathrm{A}}$} \\
\hline & $\%$ Direct effect & $\%$ Agonist effect & Drug response & $\%$ Direct effect & $\%$ Agonist effect & Drug response \\
\hline \multicolumn{7}{|l|}{ Alcohols } \\
\hline 1-decanol & None & $70 \pm 3$ & - & None & $386 \pm 20$ & + \\
\hline 1-undecanol & None & $101 \pm 2$ & 0 & None & $181 \pm 13$ & + \\
\hline 1-dodecanol & None & $98 \pm 1$ & 0 & None & $177 \pm 4$ & + \\
\hline \multicolumn{7}{|l|}{ Alkanes } \\
\hline butane & None & $7 \pm 2$ & - & None & $623 \pm 68$ & + \\
\hline pentane & None & $94 \pm 3$ & 0 & None & $321 \pm 10$ & + \\
\hline hexane & None & $100 \pm 1$ & 0 & None & $129 \pm 5$ & + \\
\hline \multicolumn{7}{|l|}{ Aldehydes } \\
\hline octanal & None & $71 \pm 3$ & - & $6 \pm 3$ & $357 \pm 20$ & + \\
\hline nonanal & None & $104 \pm 2$ & 0 & None & $219 \pm 29$ & + \\
\hline decanal & None & $97 \pm 3$ & 0 & None & $159 \pm 5$ & + \\
\hline undecanal & None & $97 \pm 8$ & 0 & None & $299 \pm 29$ & + \\
\hline \multicolumn{7}{|l|}{ Alkenes } \\
\hline 1-pentene & None & $69 \pm 1$ & - & $2 \pm 3$ & $453 \pm 38$ & + \\
\hline 1-hexene & None & $97 \pm 0$ & 0 & None & $132 \pm 2$ & + \\
\hline \multicolumn{7}{|l|}{ Alkynes } \\
\hline 1-hexyne & None & $41 \pm 6$ & - & $5 \pm 2$ & $418 \pm 21$ & + \\
\hline 1-heptyne & None & $68 \pm 10$ & - & None & $172 \pm 8$ & + \\
\hline 1-octyne & None & $96 \pm 2$ & 0 & None & $259 \pm 11$ & + \\
\hline \multicolumn{7}{|l|}{ Amines } \\
\hline 1-octadecanamine & None & $73 \pm 4$ & - & None & $146 \pm 5$ & + \\
\hline 1-eicosanamine & None & $108 \pm 1$ & 0 & None & $166 \pm 7$ & + \\
\hline \multicolumn{7}{|l|}{ Benzenes } \\
\hline 1,3-dimethylbenzene & None & $58 \pm 3$ & - & None & $366 \pm 21$ & + \\
\hline 1,3-diethylbenzene & None & $101 \pm 2$ & 0 & None & $305 \pm 24$ & + \\
\hline \multicolumn{7}{|l|}{ Cycloalkanes } \\
\hline cyclopentane & None & $83 \pm 2$ & - & $3 \pm 2$ & $196 \pm 11$ & + \\
\hline cyclohexane & None & $101 \pm 2$ & 0 & None & $421 \pm 17$ & + \\
\hline \multicolumn{7}{|l|}{ Ethers } \\
\hline dibutylether & None & $59 \pm 4$ & - & $14 \pm 13$ & $347 \pm 33$ & + \\
\hline dipentylether & None & $97 \pm 2$ & 0 & None & $211 \pm 9$ & + \\
\hline dihexylether & None & $112 \pm 4$ & 0 & None & $113 \pm 1$ & + \\
\hline \multicolumn{7}{|l|}{ Esters } \\
\hline ethyl heptanoate & None & $78 \pm 3$ & - & None & $370 \pm 34$ & + \\
\hline ethyl octanoate & None & $90 \pm 1$ & - & None & $285 \pm 18$ & + \\
\hline ethyl decanoate & None & $98 \pm 1$ & 0 & None & $137 \pm 2$ & + \\
\hline \multicolumn{7}{|l|}{ Haloalkanes } \\
\hline 1-fluoropentane & None & $76 \pm 2$ & - & None & $539 \pm 35$ & + \\
\hline 1-fluorohexane & None & $101 \pm 1$ & 0 & $11 \pm 4$ & $207 \pm 13$ & + \\
\hline 1-fluoroctane & None & $98 \pm 1$ & 0 & None & $182 \pm 18$ & + \\
\hline
\end{tabular}


Table 2 Mean responses ( \pm SEM) produced by 14 different functional groups on NMDA and GABA receptor modulation, expressed as a percent of the control agonist peak, using standard two-electrode voltage clamp techniques with 5-6 oocytes each (Continued)

\begin{tabular}{|c|c|c|c|c|c|c|}
\hline \multicolumn{7}{|l|}{ Ketones } \\
\hline 2-decaNone & None & $81 \pm 1$ & - & None & $476 \pm 52$ & + \\
\hline 2-undecaNone & None & $98 \pm 2$ & 0 & None & $230 \pm 16$ & + \\
\hline 2-dodecaNone & None & $97 \pm 3$ & 0 & None & $325 \pm 30$ & + \\
\hline \multicolumn{7}{|l|}{ Sulfides } \\
\hline 1-(ethylthio)-hexane & None & $87 \pm 1$ & - & None & $350 \pm 57$ & + \\
\hline 1-(ethylthio)-octane & None & $101 \pm 1$ & 0 & None & $120 \pm 3$ & + \\
\hline \multicolumn{7}{|l|}{ Thiols } \\
\hline 1-pentanethiol & None & $85 \pm 4$ & - & $22 \pm 8$ & $466 \pm 57$ & + \\
\hline 1-hexanethiol & None & $102 \pm 3$ & 0 & $8 \pm 2$ & $290 \pm 41$ & + \\
\hline
\end{tabular}

The \% Direct Effect is the drug response without co-administration of the receptor agonist. The \% Agonist Effect is the drug response with co-administration of agonist (glutamate and glycine for NMDA receptors; $\gamma$-aminobutyric acid for $\mathrm{GABA}_{\mathrm{A}}$ receptors). The Drug Response denotes inhibition (-) for drug + agonist responses less than the control agonist peak, potentiation (+) for drug + agonist responses greater than the control agonist peak, and no response (0) for drug + agonist responses that differ by $<10 \%$ from the control agonist peak.

amino acid residues on anesthetic-sensitive receptors, resulting in displacement of water molecules from these binding pockets and alteration of protein function [44-46]. These low energy anesthetic-protein interactions are postulated to be enthalpically favorable since the displaced water molecules should be better able to hydrogen bond with like molecules in the bulk solvent rather than with amino acids $[44,46]$. Halothane and isoflurane both have been shown to bind in water accessible pockets formed between $\alpha$-helices in $\delta$-subunits of the nicotinic acetylcholine receptor [47], a member of the 4-transmembrane receptor superfamily that includes the $\mathrm{GABA}_{\mathrm{A}}$ receptor. Models of nicotinic acetylcholine receptors and $\mathrm{GABA}_{\mathrm{A}}$ receptors further suggest that endogenous agonist or anesthetic binding might increase water accumulation in hydrophilic pockets and increase the number and accessibility of hydrophilic sites that are important for channel gating $[48,49]$. However, molecules

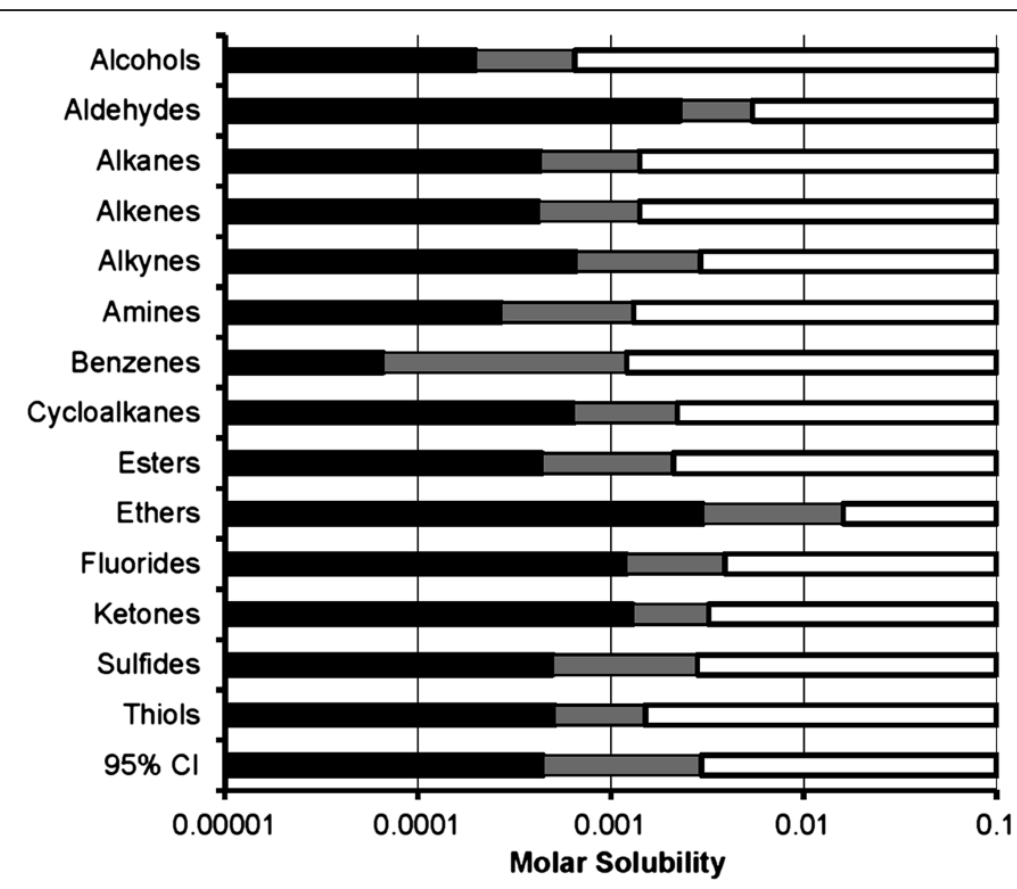

Figure 3 Summary of receptor cut-off effects as a function of molar water solubility for compounds tested in Tables 1 and 2 . For each hydrocarbon functional group, white bars represent compounds that modulate both GABA $A_{A}$ and NMDA receptors, and black bars represent compounds that modulate $G A B A_{A}$ receptors but have no effect on NMDA receptors at a saturating concentration. Intervening grey bars represent solubility values for which no data exist. 


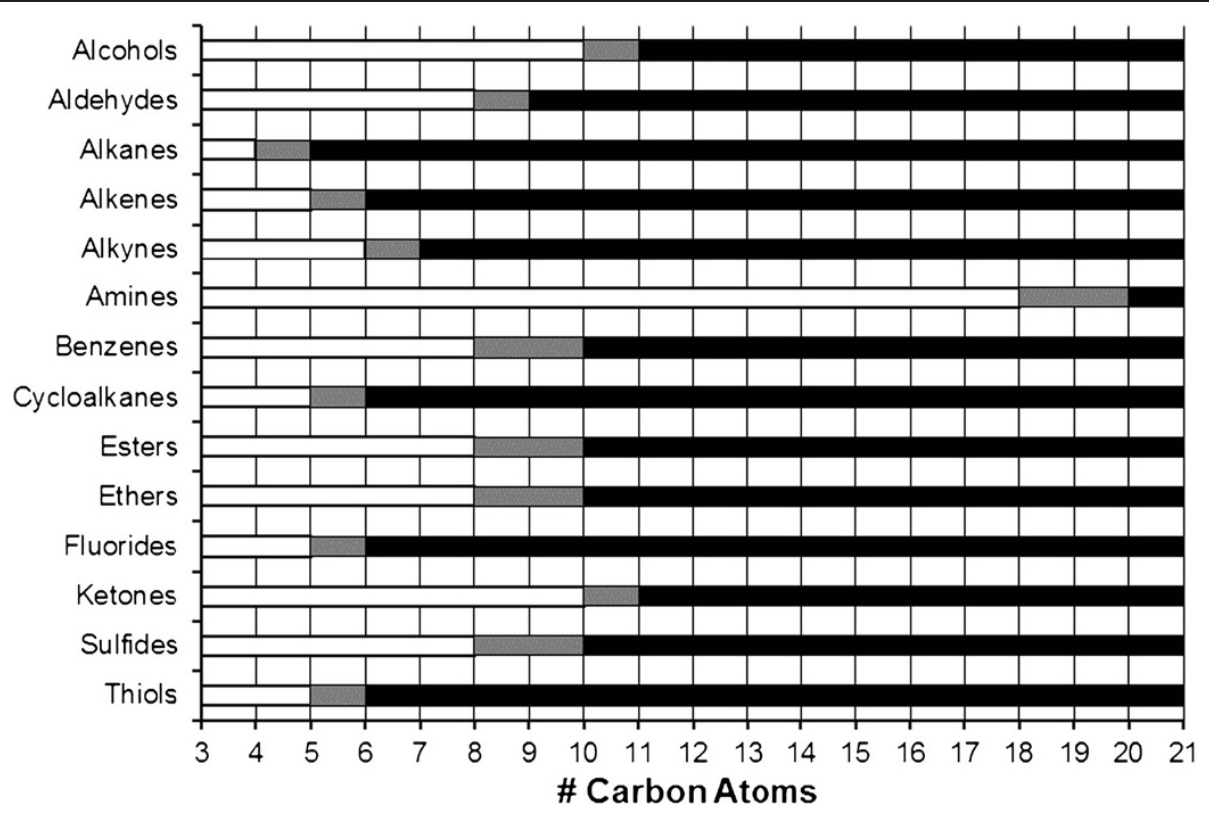

Figure 4 Summary of receptor cut-off effects as a function of the number of drug carbon atoms for compounds tested in Tables 1 and 2. For each hydrocarbon functional group, white bars represent compounds that modulate both $G_{A B A}$ and NMDA receptors, and black bars represent compounds that modulate $\mathrm{GABA}_{\mathrm{A}}$ receptors but have no effect on NMDA receptors at a saturating concentration. Intervening grey bars represent solubility values for which no data exist. No receptor cut-off pattern is evident as a function of the number of drug carbon atoms.

that are insufficiently water soluble may not be able to displace enough water molecules at enough critical sites in order to modulate channel function.

NMDA receptor modulation by inhaled anesthetics such as isoflurane, xenon, and carbon dioxide occurs- at least in part-at hydrophilic agonist binding sites $[33,50]$. However, data from the present study show that less hydrophilic drugs-those with lower molar water solubilities-are still able to modulate $\mathrm{GABA}_{\mathrm{A}}$ receptor currents even when NMDA receptor efficacy is lost. Since

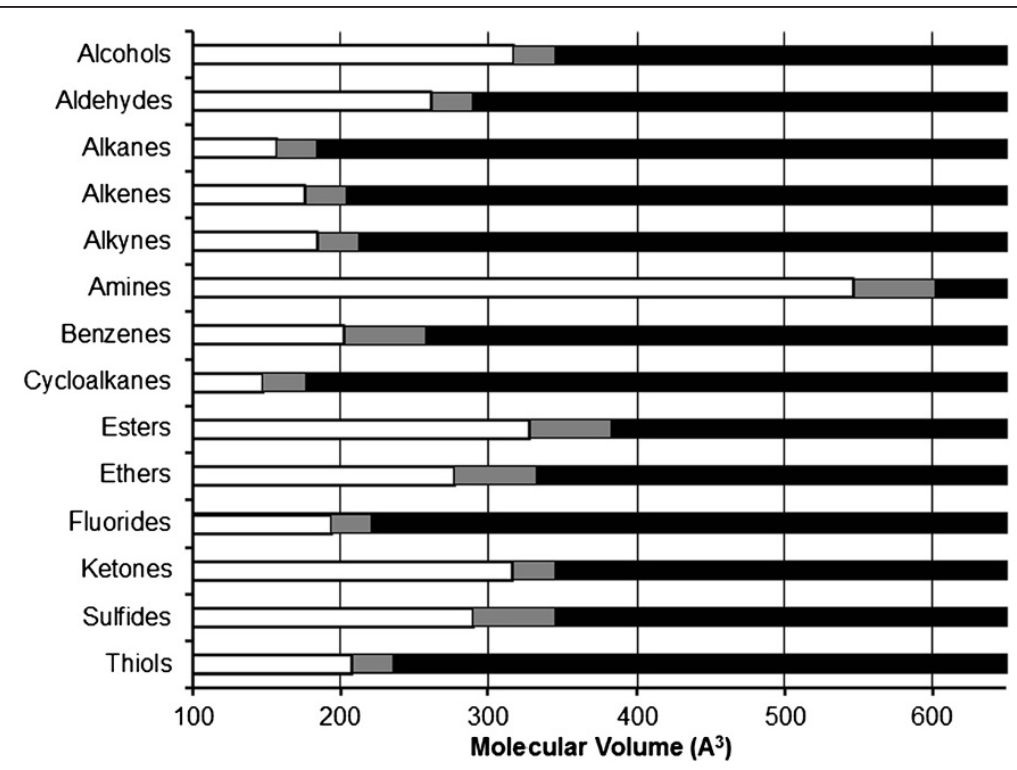

Figure 5 Summary of receptor cut-off effects as a function of the calculated molecular volume of each drug for compounds tested in Tables 1 and 2. For each hydrocarbon functional group, white bars represent compounds that modulate both GABA $A_{A}$ and NMDA receptors, and black bars represent compounds that modulate $G A B A_{A}$ receptors but have no effect on NMDA receptors at a saturating concentration. Intervening grey bars represent solubility values for which no data exist. No receptor cut-off pattern is evident as a function of molecular volume. 
these receptors belong to different and phylogenetically distinct superfamilies, it seems likely that either the number of displaced water molecules required to effect modulation, the relative affinities of the hydrocarbon versus water molecule for a critical hydrophilic protein pocket, and/or the number of hydrophilic sites necessary for allosteric modulation should also be different between proteins. Simply stated, there is no reason to suppose that unrelated channels are likely to have conserved affinity constants for water within protein cavities capable of inducing an effect on ion conductance. As evidence, GABA receptors currents, but not those of NMDA receptors, can be modulated by compounds with molar aqueous solubilities much less than $1.1 \mathrm{mM}$. Presumably, the water dissociation constant in the NMDA receptor binding site is lower than that in the analogous $\mathrm{GABA}_{\mathrm{A}}$ receptor binding site.

The locations within NMDA receptor subunits responsible for anesthetic-mediated modulation of protein function remain unresolved. However, it is likely that volatile anesthetics bind at multiple extracellular and transmembrane interfacial sites and cavities, as has been observed with nicotinic acetylcholine receptors [47,51], Gloeobacter ligand-gated ion channels [52], and voltage-gated sodium channels [53]. Whether an anesthetic positively or negatively modulates an ion channel may be a function of competing drug interactions at different sites within the protein [54]. The protein cavities must to some extent be hydrophilic so that they are occupied by water in the native state. However, if these sites are too hydrophilic, then the energy necessary for a low-affinity drug to displace the water molecules becomes too great, requiring either very high drug concentrations that alter cell effects due to changes in serum osmolality or highly polar or charged drugs which, by virtue of these properties, are impermeable to the cell membrane and therefore cannot access critical transmembrane modulatory sites.

Although the present study assessed the association between water solubility and drug efficacy on anestheticsensitive ion channels, a relationship between solubility and potency may exist as well. For example, site-directed mutagenesis of the Ala825 residue on the M4 domain of the NR2A subunit, a region at which alcohols bind and can negatively modulate NMDA receptor currents [55,56], affects potency of the slightly water-soluble hypnotic agent tribromoethanol. In fact, the hydrophobicity of the substituted amino acid negatively correlates with tribromoethanol potency as an NMDA receptor inhibitor [57]. Interestingly, except when replaced by the extremely hydrophobic tryptophan residue, which may change binding or access of water itself to the cavity, mutagenesis at this same site had no effect on the infinitely water-soluble anesthetic ethanol. Perhaps the small and highly polar ethanol molecule mimics many of the intramolecular forces, such as hydrogen bonding, of the water molecules it displaces within the binding site, thus extreme changes within the pocket are required to affect potency.

Water and lipid solubility also affect drug potency for wild-type receptors. Increasing chain length of straightchain alcohols or diols increases hydrophobicity and is initially associated with increased inhibitory potency of NMDA receptors [58,59]. Similarly, the magnitude of $\mathrm{GABA}_{\mathrm{A}}$ receptor positive modulation in the present study tended to increase as hydrocarbon chains lengthened within any functional group. This is consistent with the Meyer-Overton prediction of increased anesthetic potency as a function of increasing hydrophobicity $[60,61]$. The probability of a hydrocarbon passively entering a lipid cell membrane is parabolically related to hydrocarbon hydrophobicity; more hydrophobic molecules-up to a point-may be able to more easily access transmembrane modulatory sites [62]. However, drug solubility in the lipid membrane should not affect drug concentration in the amphipathic protein pocket, since the net energy involved in moving into and out of the lipid membrane are equal and opposite. The change in statein this case, drug diffusion in a reversible path from perfusate to lipid membrane to protein pocket-is thermodynamically defined only by the initial state (free energy in perfusate) and final state (free energy of receptor binding), and the change in free energy is independent of the membrane path between these two states [63]. However, increasingly hydrophobic molecules should differ more in their intermolecular interactions with surrounding amino acid side chains compared to the water molecules they displaced. Therefore, if they can successfully access this amphipathic pocket, increasingly hydrophobic molecules may be capable of producing larger conformational changes in the protein and greater modulation of protein function. However, as molecules become even more hydrophobic and water solubility falls below the cutoff value, there are simply insufficient molecules in the aqueous phase to successfully compete with water at hydrophilic modulation or transduction sites on a receptor to alter its function. There is progressive loss of modulatory efficacy at sites with higher cut-offs that reduces the maximum drug-effect magnitude. Finally, when the drug water solubility becomes such that it is insufficient in concentration to out-compete the water in the lowest-cut-off site, the drug effect is reduced to zero.

Likewise, in the whole animal, this plausibly explains why transitional compounds and nonimmobilizers predicted by the Meyer-Overton correlation to produce anesthesia either have lower than expected potency or lack anesthetic efficacy altogether. As with the NMDA cut-off hydrocarbons presented in the present study, transitional compounds and nonimmobilizers all share a common 
property of low aqueous solubility [64]. Nonimmobilizers such as 1,2-dichlorohexafluorocyclobutane fail to depress $\mathrm{GABA}_{\mathrm{A}}$-dependent pyramidal cells [65] or NMDAdependent CA1 neurons [66] in the hippocampus, and likely lack these effects elsewhere in the central nervous system. With decreasing water solubility, there is differential loss of receptor effects-such as occurred with NMDA receptors versus $\mathrm{GABA}_{\mathrm{A}}$ receptors in the present study. The anesthetic cut-off effect in whole animal models correlates with agent water solubility, and might be explained by the loss of one or more anesthetic-receptor contributions to central nervous system depression. Conversely, receptor molar water solubility cut-off values may be used to define those ion channels that are not essential for volatile anesthetic potency. Inhaled agents likely act via low affinity interactions with multiple cell receptors and ion channels to decrease neuronal excitability in the brain and spinal cord, but a loss or inadequate contribution from certain targets-perhaps $\mathrm{GABA}_{\mathrm{A}}$ or glycine receptors-as water solubility decreases may render a drug a nonimmobilizer. Additionally, agents having a water solubility below the cut-off value for some anesthetic-sensitive receptors may also produce undesirable pharmacologic properties, such as seizures following the loss of $\mathrm{GABA}_{\mathrm{A}}$ receptor modulation [67]. In contrast, NMDA receptors can contribute to immobilizing actions of conventional volatile anesthetics [3], but they are not as a general principle essential for inhaled anesthetic action since an agent like pentane does not modulate NMDA receptors-even at a saturated aqueous concentration (Table 2)-yet has a measurable minimum alveolar concentration $[68,69]$.

As shown in Figure 3, the different hydrocarbon series exhibit small variability about the $1.1 \mathrm{mM}$ cut-off. Some variability is due simply to the lack of compounds of intermediate solubility within a functional group series. For example, pentanethiol inhibited NMDA receptors, whereas the 1-carbon longer hexanethiol did not (Table 2). This pre-cut-off thiol is nearly 3 -times more soluble in water than its post-cut-off cognate; yet it is not possible to obtain a more narrowly defined cut-off delineation for 1-thiols. Even larger variability was observed with the dialkylbenzene series, to which 1 additional carbon was added to each 1- and 3-alkyl group. The solubility ratio between the NMDA antagonist 1,3-dimethylbenzene and its cut-off cognate 1,3-diethylbenzene is more than 18 (Table 2).

Variability about the molar water solubility NMDA receptor cut-off may also have arisen from the use of calculated, rather than measured, values for hydrocarbon molar water solubility. Aqueous solubility is difficult to measure accurately, particularly for poorly soluble substances. Calculated solubilities are more accurate for small uncharged compounds, but still can have an absolute error within $1 \log$ unit [70]. However, even predicted values for nonpolar n-alkanes may show large deviations from experimental data as the hydrocarbon chain length increases [71].

Furthermore, the molar solubility values used in the present study were calculated for pure water at $25^{\circ} \mathrm{C}$ and at $\mathrm{pH}=7.0$. These were not the conditions under which drug-receptor effects were studied. Ringer's oocyte perfusates contained buffers and physiologic concentrations of sodium, potassium, and chloride resulting in a 250 mOsm solution. The solubility of haloether and haloalkane anesthetic vapors vary inversely with osmolarity [72], as do the water-to-saline solubility ratio of benzenes, amines, and ketones [73]. The presence of salts could have caused overestimation of aqueous solubility for some compounds when using values calculated for pure water. Likewise, solubility is also temperaturedependent. Studies were conducted at $22^{\circ} \mathrm{C}$; solubility of gases in water should be greater than values calculated at $25^{\circ} \mathrm{C}$. In contrast, most solutes used in the present study have negative enthalpy for dissolution [74], so solubility should be decreased at the lower ambient temperature. The reverse should occur for exothermic solutions, as predicted by the Le Chatelier principle. As for hydronium ion concentration, the solubility of most study compounds is trivially affected at $\mathrm{pH}$ values between 7-to-8. However, hydrocarbons containing an amine group have $\mathrm{pK}_{\mathrm{a}}$ values that are closer to physiologic $\mathrm{pH}$, and the calculated aqueous solubility of 1-eicosanamine and 1-octadecanamine (Table 1) decreases by about $66 \%$ as $\mathrm{pH}$ increases from 7 to 8 . Calculated molar water solubilities for the amines in this study were probably modestly overestimated at a physiologic $\mathrm{pH}$ equal to 7.4.

Only water solubility reliably predicted the NMDA receptor cut-off. Yet, molecular size and shape still likely influence this effect to some lesser degree. Most of the hydrocarbons examined in the present study had functional groups located on the 1- or 2-carbon position. However, the ethers were all 1,1'-oxybisalkanes; each member of the ether consisted of symmetrical 1-carbon additions to alkyl groups on either side of the oxygen atom (Table 1). Consequently, this electron-rich oxygen atom allowing hydrogen bonding with water molecules or amino acid residues with strong partial positive charges lies buried in the middle of the ether. For hydrocarbons with equivalent molar water solubilities, it may be more difficult for dialkyl ether to form hydrogen bonds in hydrophilic receptor pockets compared to a long primary amine (Table 1) that might more easily insert its nucleophilic terminus into the anesthetic-binding pocket while the long hydrophobic carbon chain remains in the lipid membrane. This may explain why ethers in this study appear to exhibit an NMDA cut-off that is slightly greater than hydrocarbons with other functional groups. Perhaps if a methyl-alkyl ether series were used instead of a dialkyl 
ether series, the apparent molar water solubility cut-off for this group would have been lower. Nonetheless, the cut-off variability is sufficiently small to allow a priori predictions of low-affinity hydrocarbon modulation of NMDA receptors. It remains to be shown whether other anesthetic-sensitive ion channels exhibit distinct cut-off effects that may also be predicted by a single physical property: molar water solubility.

\section{Conclusion}

Cut-off responses for NMDA receptor inhibition by diverse hydrocarbons occurs when drug molar water solubility is less than approximately $1.1 \mathrm{mM}$. However, hydrocarbons having lower molar water solubilities are still able to potentiate $\mathrm{GABA}_{\mathrm{A}}$ receptors. This finding supports a hypothesis that volatile compounds, such as inhaled anesthetics, access one or more amphipathic "pockets" within a protein, such as the NMDA receptor, to displace resident water molecules and induce a conformational change. Volatile anesthetics and other compounds with insufficient molar water solubility can never achieve sufficient concentration at the amphipathic pocket site to displace water and modulate protein functioneven when such compounds are administered at a saturated aqueous phase concentration.

\section{Competing interests}

The authors declare that they have no competing interests.

\section{Authors' contributions}

RB: Developed hypothesis, designed experiments, assisted with experiments, analyzed data, and wrote the manuscript. TP: Conducted experiments and reviewed the manuscript. Both authors read and approved the final manuscript.

\section{Acknowledgements}

This entirety of this work was funded by the National Institutes of Health National Institutes of General Medical Sciences (Grant GM092821-02).

Received: 2 June 2014 Accepted: 13 November 2014

Published: 19 November 2014

\section{References}

1. Brosnan RJ: Inhaled anesthetics in horses. Vet Clin North Am Equine Pract 2013, 29(1):69-87.

2. Chau PL: New insights into the molecular mechanisms of general anaesthetics. Br J Pharmacol 2010, 161(2):288-307.

3. Stabernack C, Sonner JM, Laster M, Zhang Y, Xing Y, Sharma M, Eger El 2nd: Spinal N-methyl-d-aspartate receptors may contribute to the immobilizing action of isoflurane. Anesth Analg 2003, 96(1):102-107.

4. Rau V, Oh I, Liao M, Bodarky C, Fanselow MS, Homanics GE, Sonner JM, Eger El 2nd: Gamma-aminobutyric acid type A receptor beta3 subunit forebrain-specific knockout mice are resistant to the amnestic effect of isoflurane. Anesth Analg 2011, 113(3):500-504.

5. Rau V, lyer SV, Oh I, Chandra D, Harrison N, Eger El 2nd, Fanselow MS, Homanics GE, Sonner JM: Gamma-aminobutyric acid type A receptor alpha 4 subunit knockout mice are resistant to the amnestic effect of isoflurane. Anesth Analg 2009, 109(6):1816-1822.

6. Dutton RC, Laster MJ, Xing Y, Sonner JM, Raines DE, Solt K, Eger El 2nd: Do N-methyl-D-aspartate receptors mediate the capacity of inhaled anesthetics to suppress the temporal summation that contributes to minimum alveolar concentration? Anesth Analg 2006, 102(5):1412-1418.
7. Mayer ML: Glutamate receptors at atomic resolution. Nature 2006, 440(7083):456-462.

8. Ernst M, Bruckner S, Boresch S, Sieghart W: Comparative models of GABAA receptor extracellular and transmembrane domains: important insights in pharmacology and function. Mol Pharmacol 2005, 68(5):1291-1300.

9. Nistri A, Berti C: Potentiating action of midazolam on GABA-mediated responses and its antagonism by Ro 14-7437 in the frog spinal cord. Neurosci Lett 1983, 39(2):199-204.

10. Macdonald R, Barker JL: Benzodiazepines specifically modulate GABAmediated postsynaptic inhibition in cultured mammalian neurones. Nature 1978, 271(5645):563-564.

11. Dildy-Mayfield JE, Mihic SJ, Liu Y, Deitrich RA, Harris RA: Actions of long chain alcohols on GABAA and glutamate receptors: relation to in vivo effects. Br J Pharmacol 1996, 118(2):378-384.

12. Flood P, Krasowski MD: Intravenous anesthetics differentially modulate ligand-gated ion channels. Anesthesiology 2000, 92(5):1418-1425.

13. Kendig JJ, Kodde A, Gibbs LM, lonescu P, Eger El 2nd: Correlates of anesthetic properties in isolated spinal cord: cyclobutanes. Eur J Pharmacol 1994, 264(3):427-436.

14. Jenkins A, Franks NP, Lieb WR: Effects of temperature and volatile anesthetics on GABA(A) receptors. Anesthesiology 1999, 90(2):484-491.

15. Krasowski MD, Harrison NL: The actions of ether, alcohol and alkane general anaesthetics on GABAA and glycine receptors and the effects of TM2 and TM3 mutations. Br J Pharmacol 2000, 129(4):731-743.

16. Hollmann MW, Liu HT, Hoenemann CW, Liu WH, Durieux ME: Modulation of NMDA receptor function by ketamine and magnesium. Part II: interactions with volatile anesthetics. Anesth Analg 2001, 92(5):1182-1191.

17. Nishikawa K, Harrison NL: The actions of sevoflurane and desflurane on the gamma-aminobutyric acid receptor type A: effects of TM2 mutations in the alpha and beta subunits. Anesthesiology 2003, 99(3):678-684.

18. Yamakura T, Sakimura K, Shimoji K, Mishina M: Effects of propofol on various AMPA-, kainate- and NMDA-selective glutamate receptor channels expressed in Xenopus oocytes. Neurosci Lett 1995, 188(3):187-190.

19. Hales TG, Lambert JJ: The actions of propofol on inhibitory amino acid receptors of bovine adrenomedullary chromaffin cells and rodent central neurones. Br J Pharmacol 1991, 104(3):619-628.

20. Yamakura T, Chavez-Noriega LE, Harris RA: Subunit-dependent inhibition of human neuronal nicotinic acetylcholine receptors and other ligandgated ion channels by dissociative anesthetics ketamine and dizocilpine. Anesthesiology 2000, 92(4):1144-1153.

21. Yamakura T, Harris RA: Effects of gaseous anesthetics nitrous oxide and xenon on ligand-gated ion channels. Comparison with isoflurane and ethanol. Anesthesiology 2000, 93(4):1095-1101.

22. Ogata J, Shiraishi M, Namba T, Smothers CT, Woodward JJ, Harris RA: Effects of anesthetics on mutant $\mathrm{N}$-methyl-D-aspartate receptors expressed in Xenopus oocytes. J Pharmacol Exp Ther 2006, 318(1):434-443.

23. Martin DC, Plagenhoef M, Abraham J, Dennison RL, Aronstam RS: Volatile anesthetics and glutamate activation of $\mathrm{N}$-methyl-D-aspartate receptors. Biochem Pharmacol 1995, 49(6):809-817.

24. Wong EH, Kemp JA, Priestley T, Knight AR, Woodruff GN, Iversen LL: The anticonvulsant MK-801 is a potent N-methyl-D-aspartate antagonist. Proc Natl Acad Sci U S A 1986, 83(18):7104-7108.

25. Hara K, Eger El 2nd, Laster MJ, Harris RA: Nonhalogenated alkanes cyclopropane and butane affect neurotransmitter-gated ion channel and G-protein-coupled receptors: differential actions on GABAA and glycine receptors. Anesthesiology 2002, 97(6):1512-1520.

26. Krasowski MD, Jenkins A, Flood P, Kung AY, Hopfinger AJ, Harrison NL: General anesthetic potencies of a series of propofol analogs correlate with potency for potentiation of gamma-aminobutyric acid (GABA) current at the GABA(A) receptor but not with lipid solubility. J Pharmacol Exp Ther 2001, 297(1):338-351.

27. Vemparala S, Saiz L, Eckenhoff RG, Klein ML: Partitioning of anesthetics into a lipid bilayer and their interaction with membrane-bound peptide bundles. Biophys J 2006, 91(8):2815-2825.

28. Stimson LM, Vattulainen I, Rog T, Karttunen M: Exploring the effect of xenon on biomembranes. Cell Mol Biol Lett 2005, 10(4):563-569.

29. Pohorille A, Wilson MA, New MH, Chipot C: Concentrations of anesthetics across the water-membrane interface; the Meyer-Overton hypothesis revisited. Toxicol Lett 1998, 100-101:421-430.

30. Brosnan R, Gong D, Cotten J, Keshavaprasad B, Yost CS, Eger El 2nd, Sonner JM: Chirality in anesthesia II: stereoselective modulation of ion 
channel function by secondary alcohol enantiomers. Anesth Analg 2006, 103(1):86-91.

31. Yang L, Milutinovic PS, Brosnan RJ, Eger El 2nd, Sonner JM: The plasticizer di(2-ethylhexyl) phthalate modulates gamma-aminobutyric acid type $\mathrm{A}$ and glycine receptor function. Anesth Analg 2007, 105(2):393-396.

32. Yang L, Zhao J, Milutinovic PS, Brosnan RJ, Eger El 2nd, Sonner JM: Anesthetic properties of the ketone bodies beta-hydroxybutyric acid and acetone. Anesth Analg 2007, 105(3):673-679.

33. Brosnan RJ, Pham TL: Does anesthetic additivity imply a similar molecular mechanism of anesthetic action at $\mathrm{N}$-methyl-D-aspartate receptors? Anesth Analg 2011, 112(3):568-573.

34. Brosnan RJ, Pham TL: Carbon dioxide negatively modulates N-methyl-Daspartate receptors. Br J Anaesth 2008, 101(5):673-679.

35. Eger El 2nd, Halsey MJ, Harris RA, Koblin DD, Pohorille A, Sewell JC, Sonner JM, Trudell JR: Hypothesis: volatile anesthetics produce immobility by acting on two sites approximately five carbon atoms apart. Anesth Analg 1999, 88(6):1395-1400.

36. Jenkins A, Greenblatt EP, Faulkner HJ, Bertaccini E, Light A, Lin A, Andreasen A, Viner A, Trudell JR, Harrison NL: Evidence for a common binding cavity for three general anesthetics within the GABAA receptor. J Neurosci 2001, 21(6): RC136

37. Wick MJ, Mihic SJ, Ueno S, Mascia MP, Trudell JR, Brozowski SJ, Ye Q, Harrison NL, Harris RA: Mutations of gamma-aminobutyric acid and glycine receptors change alcohol cutoff: evidence for an alcohol receptor? Proc Natl Acad Sci U S A 1998, 95(11):6504-6509.

38. Eger El 2nd, Laster MJ: The effect of rigidity, shape, unsaturation, and length on the anesthetic potency of hydrocarbons. Anesth Analg 2001, 92(6):1477-1482.

39. Franks NP, Lieb WR: Selective actions of volatile general anaesthetics at molecular and cellular levels. Br J Anaesth 1993, 71(1):65-76.

40. Tomlin SL, Jenkins A, Lieb WR, Franks NP: Stereoselective effects of etomidate optical isomers on gamma-aminobutyric acid type A receptors and animals. Anesthesiology 1998, 88(3):708-717.

41. Tonner PH, Scholz J, Koch C, Schulte am Esch J: The anesthetic effect of dexmedetomidine does not adhere to the Meyer-Overton rule but is reversed by hydrostatic pressure. Anesth Analg 1997, 84(3):618-622

42. Pert CB, Snyder SH: Properties of opiate-receptor binding in rat brain. Proc Natl Acad Sci U S A 1973, 70(8):2243-2247.

43. Trudell JR, Bertaccini E: Molecular modelling of specific and non-specific anaesthetic interactions. Br J Anaesth 2002, 89(1):32-40.

44. Bertaccini EJ, Trudell JR, Franks NP: The common chemical motifs within anesthetic binding sites. Anesth Analg 2007, 104(2):318-324.

45. Abraham MH, Lieb WR, Franks NP: Role of hydrogen bonding in general anesthesia. J Pharm Sci 1991, 80(8):719-724.

46. Streiff $\mathrm{JH}$, Jones $\mathrm{KA}$ : Volatile anesthetic binding to proteins is influenced by solvent and aliphatic residues. J Chem Inf Model 2008, 48(10):2066-2073.

47. Chiara DC, Dangott $\amalg$, Eckenhoff RG, Cohen JB: Identification of nicotinic acetylcholine receptor amino acids photolabeled by the volatile anesthetic halothane. Biochemistry 2003, 42(46):13457-13467.

48. Williams DB, Akabas MH: Gamma-aminobutyric acid increases the water accessibility of M3 membrane-spanning segment residues in gammaaminobutyric acid type A receptors. Biophys J 1999, 77(5):2563-2574.

49. Willenbring $D, X u Y$, Tang P: The role of structured water in mediating general anesthetic action on alpha4beta2 nAChR. Phys Chem Chem Phys 2010, 12(35):10263-10269.

50. Dickinson R, Peterson BK, Banks P, Simillis C, Martin JC, Valenzuela CA, Maze M, Franks NP: Competitive inhibition at the glycine site of the N-methyl$\mathrm{D}$-aspartate receptor by the anesthetics xenon and isoflurane: evidence from molecular modeling and electrophysiology. Anesthesiology 2007, 107(5):756-767.

51. Brannigan G, LeBard DN, Henin J, Eckenhoff RG, Klein ML: Multiple binding sites for the general anesthetic isoflurane identified in the nicotinic acetylcholine receptor transmembrane domain. Proc Natl Acad Sci U S A 2010, 107(32):14122-14127.

52. Chen $\mathrm{Q}$, Cheng $\mathrm{MH}, \mathrm{Xu}$ Y, Tang $\mathrm{P}$ : Anesthetic binding in a pentameric ligand-gated ion channel: GLIC. Biophys J 2010, 99(6):1801-1809.

53. Raju SG, Barber AF, LeBard DN, Klein ML, Carnevale V: Exploring volatile general anesthetic binding to a closed membrane-bound bacterial voltage-gated sodium channel via computation. PLOS Comput Biol 2013, 9(6):e1003090
54. Bromstrup T, Howard RJ, Trudell JR, Harris RA, Lindahl E: Inhibition versus potentiation of ligand-gated ion channels can be altered by a single mutation that moves ligands between intra- and intersubunit sites. Structure 2013, 21(8):1307-1316.

55. Xu M, Smothers CT, Trudell J, Woodward JJ: Ethanol inhibition of constitutively open $\mathrm{N}$-methyl-D-aspartate receptors. J Pharmacol Exp Ther 2012, 340(1):218-226.

56. Ren H, Zhao Y, Dwyer DS, Peoples RW: Interactions among positions in the third and fourth membrane-associated domains at the intersubunit interface of the N-methyl-D-aspartate receptor forming sites of alcohol action. J Biol Chem 2012, 287(33):27302-27312.

57. Salous AK, Ren H, Lamb KA, Hu XQ, Lipsky RH, Peoples RW: Differential actions of ethanol and trichloroethanol at sites in the M3 and M4 domains of the NMDA receptor GluN2A (NR2A) subunit. Br J Pharmacol 2009, 158(5):1395-1404.

58. Peoples RW, Ren H: Inhibition of N-methyl-D-aspartate receptors by straight-chain diols: implications for the mechanism of the alcohol cutoff effect. Mol Pharmacol 2002, 61(1):169-176

59. Peoples RW, Weight FF: Cutoff in potency implicates alcohol inhibition of $\mathrm{N}$-methyl-D-aspartate receptors in alcohol intoxication. Proc Natl Acad SCi U S A 1995, 92(7):2825-2829.

60. Mihic SJ, McQuilkin SJ, Eger El 2nd, lonescu P, Harris RA: Potentiation of gamma-aminobutyric acid type A receptor-mediated chloride currents by novel halogenated compounds correlates with their abilities to induce general anesthesia. Mol Pharmacol 1994, 46(5):851-857.

61. Horishita T, Eger El 2nd, Harris RA: The effects of volatile aromatic anesthetics on voltage-gated $\mathrm{Na}+$ channels expressed in Xenopus oocytes. Anesth Analg 2008, 107(5):1579-1586.

62. Hansch C, Fujita T: $\mathrm{p}-\sigma-\pi$ Analysis. A Method for the Correlation of Biological Activity and Chemical Structure. J Am Chem Soc 1964, 86(8):1616-1626.

63. Fermi E: Thermodynamics. New York, NY: Prentice-Hall; 1937.

64. Eger El 2nd: Mechanisms of Inhaled Anesthetic Action. In The Pharmacology of Inhaled Anesthetics. Volume 1. Edited by Eger El 2nd. IL, USA: Baxter Healthcare Corporation; 2002:33-42.

65. Perouansky M, Banks MI, Pearce RA: The differential effects of the nonimmobilizer 1,2-dichlorohexafluorocyclobutane (F6, $2 \mathrm{~N})$ and isoflurane on extrasynaptic gamma-aminobutyric acid A receptors. Anesth Analg 2005, 100(6):1667-1673.

66. Taylor DM, Eger El 2nd, Bickler PE: Halothane, but not the nonimmobilizers perfluoropentane and 1,2-dichlorohexafluorocyclobutane, depresses synaptic transmission in hippocampal CA1 neurons in rats. Anesth Analg 1999, 89(4):1040-1045.

67. Raines DE: Anesthetic and nonanesthetic halogenated volatile compounds have dissimilar activities on nicotinic acetylcholine receptor desensitization kinetics. Anesthesiology 1996, 84(3):663-671.

68. Liu J, Laster MJ, Taheri S, Eger El 2nd, Koblin DD, Halsey MJ: Is there a cutoff in anesthetic potency for the normal alkanes? Anesth Analg 1993, 77(1):12-18

69. Taheri S, Laster MJ, Liu J, Eger El 2nd, Halsey MJ, Koblin DD: Anesthesia by $\mathrm{n}$-alkanes not consistent with the Meyer-Overton hypothesis: determinations of the solubilities of alkanes in saline and various lipids. Anesth Analg 1993, 77(1):7-11.

70. Delaney JS: Predicting aqueous solubility from structure. Drug Discov Today 2005, 10(4):289-295.

71. Ferguson AL, Debenedetti PG, Panagiotopoulos AZ: Solubility and molecular conformations of $\mathrm{n}$-alkane chains in water. J Phys Chem 2009, 113(18):6405-6414.

72. Lerman J, Willis MM, Gregory GA, Eger El 2nd: Osmolarity determines the solubility of anesthetics in aqueous solutions at 37 degrees $\mathrm{C}$. Anesthesiology 1983, 59(6):554-558.

73. Long FA, McDevit WF: Activity coefficients of nonelectrolyte solutes in aqueous salt solutions. Chem Rev 1952, 51(1):119-169.

74. Abraham MH: Free energies, enthalpies, and entropies of solution of gaseous nonpolar nonelectrolytes in water and nonaqueous solvents The hydrophobic effect. J Am Chem Soc 1982, 104(8):2085-2094.

doi:10.1186/2050-6511-15-62

Cite this article as: Brosnan and Pham: Hydrocarbon molar water solubility predicts NMDA vs. GABA $A_{A}$ receptor modulation. BMC Pharmacology and Toxicology 2014 15:62. 